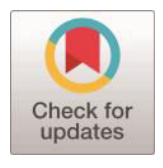

Article Type: Research Paper

\section{Nexus between Issue of Environmental Pollution and the Urban Population: Evidence of Economic Growth in Indonesia}

\author{
Lutfi Asnan Qodri* and Setyo Tri Wahyudi
}

Abstract: This study aims to analyze the factors that cause climate change that occurs in Indonesia. From every effort to increase economic growth, some elements are sacrificed. The Oil Palm Industry, high levels of $\mathrm{CO}_{2}$ emissions, Gini ratio index, and population increase in urban areas are variables used in this research. This research was conducted for thirty years, from 1990 to 2020 . The analysis model used was the Vector Error Correction Model (VECM). The estimation results show that the palm oil industry, the impact of $\mathrm{CO}_{2}$ emissions, and the increase in urban population have a positive effect in the long term but do not impact economic growth in the long term because one of them is environmental quality degradation. Therefore, sometimes every effort to increase economic growth must be accompanied by mitigation of environmental impacts that will affect the short and long term.

Keywords: Palm Oil Industry; $\mathrm{CO}_{2}$ Emissions; Gini Ratio Index; Environmental Quality

JEL Classification: R5; Q5; 02

\section{Introduction}

The world is currently in the midst of a disaster, namely climate change, that can impact our lives in the future. In recent years, there has been much discussion about the impacts and how to deal with climate change that is currently happening (Sommer et al., 2019; Sorsa \& Fougère, 2020). One of the causes is deforestation (Shao et al., 2019). The current loss of green forest ecosystems continues to decrease, as evidenced by the fact that 2.9 million hectares of forest availability have decreased by as much as $40 \%$. It happens because developing countries tend to ignore the opening of new industries that take up many green forests and (Vijay et al., 2016). In addition, of course, continuous deforestation will impact the loss of biodiversity contained therein (Union of Concerned Scientists, 2018).

One of the goals of deforestation is for the expansion of the palm oil industry. Bahuet (2017) stated that the palm oil commodity is one of the most widely consumed commodities globally, especially in China, India, and the European Union (EU). With a total population of 1.3 billion people, India is the largest consumer of palm oil production globally (USDA, 2021). Indonesia and Malaysia are the largest suppliers of palm oil commodities globally, where $80 \%$ of the world's demand for palm oil comes from this country (FAO, 2018). 
When viewed from the availability of land for oil palm, there are 3.51 million hectares of land used for RSPO (Round table on Sustainable Palm Oil) certified oil palm plantations. The land is capable of producing 13.18 million tonnes of palm oil. It accounts for $21 \%$ of the global demand for palm oil (Jakob \& Merk, 2011). Of course, various nongovernmental organizations deeply regret monitoring and enforcing certification standard rules because this certification does not favor the sustainability of ecosystems in nature itself. (Greenpeace, 2013; Kadarusman \& Herabadi, 2018). Furthermore, what is no less worrying is the sale and purchase of oil palm land, which RSPO member companies deliberately trade and resale to the global market. (Laurance et al., 2010).

Even climate change cannot be avoided from the current phenomenon of life (Brown et al., 2019). Instead of aiming to improve the country's economy but sacrificing the existence of nature. In case, climate change is a challenge for every country in the $21^{\text {st }}$ century (Espeland \& Kettenring, 2018; Shao et al., 2019). One of the causes of climate change is that several developing countries emit GHG emissions from inefficient fossil fuels, Indonesia. In Indonesia, palm oil is a potential source of state income. In addition, the palm oil industry in Indonesia can bring in foreign direct investment, which is an essential factor in economic growth. However, sadly, it is not accompanied by environmentally friendly management and technology for ecological sustainability (Li \& Wang, 2017; Yang \& Li, 2017).

Climate change is also exacerbated by the high number of people moving from villages to cities or commonly referred to as urbanization (Argüeso et al., 2013). More than 54 percent of the people live in urban areas. The quality of life that is often shown from a picture of life in urban areas makes the main attraction for urbanization (UN, 2014). People who cannot compete will be easily excluded from urban life. Being isolated makes life even more unworthy and creates a new poverty and inequality ratio (Luber \& McGeehin, 2008).

In Indonesia, the palm oil industry is the most significant contributor to national development (Purnomo et al., 2020). In 2017 Indonesia managed to export \$23 billion of palm oil. The role of the palm oil industry is $17 \%$ of gross domestic product. Of course, in this case, the Indonesian government has set a target for palm oil production starting in 2010. The Indonesian government is targeting a production target of 40 million tons by 2020. (Reiley, 2018). the Gol set a productivity target known as" Vision 35:26" to produce 35 tons per hectare (ha) of fresh fruit bunches (FFBs) with a $26 \%$ oil extraction rate. The Indonesian government also plans to undertake governance reforms on 9 million ha of land for smallholder practices, including oil palm (Setkab, 2015). The expansion of oil palm plantations aims to support Indonesia's economic growth target of more than $5 \%$ for $2017-2018$.

At the same time, in the National Determined Contribution (NDC), as an effort to realize the Paris agreement, in this case, Indonesia agreed to reduce carbon emissions by $29 \%$ without foreign intervention by 2030 and by $41 \%$ with foreign intervention. In a business-as-usual (BAU) scenario, emissions reached 2.881 gigatons of $\mathrm{CO}_{2}$ equivalent $\left(\mathrm{CO}_{2 \mathrm{e}}\right)$ in 2030 . To achieve this, Indonesia can take a policy, namely implementing a 
sustainable-based agriculture and plantation system, reducing deforestation and land conversion, and realizing renewable energy from land that has already been degraded.

Mubekti (2013) Forest conversion and peatland processing have changed the function of peatlands from carbon sequestration to a source of greenhouse gas emissions. Excessive emission of carbon dioxide $\mathrm{CO}_{2}$ can increase greenhouse gases in the atmosphere, which will impact an increase in climate change (Atik, 2012). Based on statistics from BP Statistics World, total carbon dioxide emissions have increased by about 5.4 times, from 1429 million tons (Mt) to $9208 \mathrm{Mt}$, during the period 1978 and 2012 in China.

The impact of land clearing for the palm oil industry is that every one hectare of forest land will remove 174 tons of carbon, and most of it finds its way into the air. (Science Daily, 2021) In fact, according to research, it is a fact that new oil palm plantations produce more carbon gas than old lands. (Sjogersten, 2020) It means that the increase in the area of oil palm plantations from year to year, as statistical data from the DirectorGeneral of Plantations, is commensurate with the increase in carbon gas levels in the air resulting from the activity of opening oil palm plantations, or it could be more considering that there are illegal oil palm plantations that are growing. Its validity is unknown. In addition, there are other impacts on the environment, such as water and soil pollution, soil erosion, and climate change (S \& Marshall R T, 1996).

Land clearing by burning as well as the conversion of tropical peat forests in Indonesia is very damaging to the existing biodiversity system, as this "carbon" "sink" stores more carbon per unit area than any other ecosystem in the world (Ruggeri, 2019). In addition, forest fires usually occur as vegetation in the development of oil palm plantations is a source of carbon dioxide that contributes to climate change (Brown et al., 2019). Due to the high rate of deforestation, Indonesia is the third-largest emitter of greenhouse gases in the world (Kumar, 2019).

Palm oil is a commodity with a high demand level in local, regional, and international markets. Because palm oil can be used as a variety of products for household needs, food processing needs, cosmetic needs, biodiesel, and biogas needs (Khatun et al., 2017). Therefore, some entrepreneurs are expanding to clear oil palm land to meet market demand, not only entrepreneurs but also oil palm farmers.

In Indonesia, some regulations include permits for land conversion for land clearing for palm oil, which is regulated in the Minister of Agriculture Regulation No. 98 of 2013 as amended by Minister of Agriculture Regulation No. 29 of 2016 and finally amended by Minister of Agriculture Regulation No. 21 of 2019 (Eka Yulian et al., 2018). There are two types of regulated plantation businesses and three different permits. However, these regulations tend to only focus on the side of economic benefits (Perisai, 2020). Lack of attention to the long-term impacts of land conversion for the palm oil industry (Amalia et al., 2019).

The expansion of the oil palm plantation industry does bring added value to farmer households. The expansion of the oil palm plantation industry does bring added value to 
farmer households (Wicke et al., 2011). However, this also creates a dilemma for the community because they lose the future sustainability of biodiversity systems. Society also tends to experience a shift in a lifestyle where the sub-sustenance first changes to a materialistic orientation (Eka Yulian et al., 2018). However, if viewed the benefits for the government, the expansion of oil palm plantations adds to the country's foreign exchange at the national level (GAPKI, 2016).

Urbanization, which is the movement of people from villages to cities, is an equally important problem for Indonesia (Sulistyorini, 2020). The level of human population and all its activities is the most significant contributor to greenhouse gas emissions that trigger global warming. However, researchers are now discovering that it is not just the size of the human population that impacts the planet's health. The composition of the population and the location in which they live also plays a significant role in greenhouse gas emissions. Statistical data shows that in Indonesia, there has been an increase in urbanization since 2008. In 2008, the city's population amounted to $48 \%$ and increased for ten years to $55.33 \%$. It is in contrast to what was conveyed by several village heads who claimed $70 \%$ of the Indonesian population was living in villages when they were advocating for funding from the central government. (Sulistyorini, 2020). However, if you look at the average level of the population living in urban areas in the world, which is only $40 \%$, it can be said that the number of urban residents in Indonesia is greater than the average population living in cities in the world.

Suppose we look at the factors that influence the high level of urbanization in Indonesia, development inequality between cities and villages. Especially in public facilities, construction of road access, and the ease of getting a job. Therefore, urban areas are still the only solution for rural communities to get jobs (Rahmawati, 2020). Therefore, problems will tend to arise in urban areas, where people flock in search of temporary housing to survive while they do not have a decent place to live. The struggle for land often becomes a new problem in the social field where the new community is likened to a junior carrying out an internship at a company with a high level of discipline. When they cannot, they will be eliminated without mercy until finally increasing Indonesia's poverty level.

Indeed this can have an impact on climate change in Indonesia. As in Jakarta, the impact of urbanization on the climate is that in the lowlands of Jakarta, the temperature was relatively high before the dominance of urbanization occurred. However, the existence of urbanization with built-up land tenure is increasing the air temperature. On the other hand, the further south of Jakarta, the temperature change is not too significant because it is a highland that initially has a lower temperature (Etale \& Simatele, 2021; Zeigler, 2019). Therefore, as a recommendation, it is necessary to affirm climate control through controlling land cover changes, including creating green-building, limiting development, and revitalizing green belts in Greater Jakarta to prevent other conurbation. (Heizmann \& Huth, 2021).

In this regard, we aim to identify existing literature, summarize some that have been done previously and see the extent to which several efforts to improve the economy in 
Indonesia are related to the existing climate. What makes it different from other studies is that it does not mention the effect of the Gini ratio index variable on climate change. It is very rarely found in some existing literature, especially in Indonesia. Most of the literature only looks at the side variables that support economic growth, but one of the negative impacts is climate change.

\section{Research Method}

This study uses a quantitative method using the Vector Error Correction Regression (VECM) approach. It is done to understand the correlation between variables (Shao et al., 2019). The data used for this study were collected from the Global Energy Statistical Yearbook 2020, Worldometer, and Statistics Indonesia (BPS), World Bank Data. The research was conducted for thirty years, from 1990 to 2020. Therefore, the data to be analyzed is annual data so that it accumulates for 30 years.

Table 1 Variables and secondary data sources

\begin{tabular}{|c|c|c|c|}
\hline NO & Variable & Symbol & Source \\
\hline 1 & Economic Growth & EG & Statistics Indonesia (BPS) Indonesia \\
\hline 2 & Emisi Gas mtCO 2 (GE, & GE & $\begin{array}{l}\text { Global Energy Statistical Yearbook } \\
2020\end{array}$ \\
\hline 3 & Crude Palm Oil (CPO) & $\mathrm{CPO}$ & $\begin{array}{l}\text { Global Energy Statistical Yearbook } \\
2020\end{array}$ \\
\hline 4 & Urban Populations (UP), & UP & Worldometer, \\
\hline 5 & Indeks Gini Ratio (GRI) & GRI & World Bank Data \\
\hline
\end{tabular}

Furthermore, the data were analyzed using the Vector Error Correction Model (VECM) using E-Views (version 11). The reason is that this model can provide both long-term and short-term influence points of view. Therefore, it is necessary to focus this research on Indonesia, considering that this country is one of the largest palm oil producers globally (Kadarusman \& Herabadi, 2018). In more detail, the variables of this study are presented in Table 1. The variables in this study are Economic Growth (EG), Gas Emissions $m t_{C O}$ (GE), Crude Palm Oil (CPO), Urban Populations (UP), and Gini Ratio Index (GRI). In addition, the following are the specifications of the VECM model:

$$
\Delta y t=\mu 0 x+\mu 1 x t+\Pi x y t-1+\sum i k \Delta y t-1+\varepsilon t
$$

$y t=$ Vector containing variables analyzed in research, $\mu 0 \mathrm{x}=$ Intercept Vector, $\mu 1 \mathrm{x}=$ Regression Coefficient Vector, $t=$ Time Trend, $\Pi x=\alpha \times \beta^{\prime}$ where $b^{\prime}$ consist long-term cointegration equation, $\mathrm{yt}-1=$ Variabel in level, $\Gamma \mathrm{ik}=$ Regression coefficient matrix, $\mathrm{k}-1=$ Ordo VECM from VAR, $\varepsilon t=$ Error Term 
VECM modeling based on the variables used is as follows:

$$
\begin{gathered}
\Delta E G=a+\sum_{i=1}^{n} \beta i \Delta E G_{t-i}+\sum_{i=1}^{n} \beta i \Delta G E_{t-i}+\sum_{i=1}^{n} \beta i \Delta C P O_{t-i}+\sum_{i=1}^{n} \beta i \Delta U P_{t-i} \\
+\sum_{i=1}^{n} \beta i \Delta G R I_{t-i}+\lambda E C_{t-1}+\varepsilon_{t}
\end{gathered}
$$

The meaning of the equation $\triangle E G$ is Economic Growth di Indonesia, $\beta i \triangle G E_{t-i}$ is Gas Emission, $\beta i \triangle C P O_{t-i}$ is Production Crude Palm Oil in Indonesia, $\beta i \Delta U P_{t-i}$ is Urban Population, $\beta i \Delta G R I_{t-i}$ is Gini Ratio Index in Indonesia.

In conducting the VAR test, several steps must be taken, and this is in the context of preestimation tests and validation tests before carrying out tests at the core. These steps are Stationarity, Lag, Cointegration, and Vector Error Correction Model (VECM) test.

The stationarity test of time series economic data is generally stochastic or has a trend that is not stationary, meaning that the data contains unit roots. Therefore, to estimate a model using these data, the first step needed is the stationarity test of the data. The data stationarity test is also known as the unit root test. The unit root test will be carried out in this study using Augmented Dickey-Fuller (ADF). If the t-statistic value of ADF is smaller than the MacKinnon table, then the decision is to reject $\mathrm{HO}$ and vice versa. Therefore, when it is concluded that if there is no unit root, it can be concluded that the time series data is stationary.

$$
\Delta Y_{t}=a_{0}+z_{t}+a_{1} Y_{t-1}++\sum_{i=1}^{p} a i \Delta Y_{t}-1+\varepsilon_{t}
$$

It is means a_0 constant, $\mathrm{t}$ is a deterministic trend, $\boldsymbol{\varepsilon}$ is an error term. IFor example, if the autoregressive of $Y\left(Y_{-}(t-1)\right)$ contains a unit root, then the ratio $t$ ( $t$ ratio) for a_1 should be consistent with the hypothesis a_1 $1=0$.

Determination of Optimal Lag The second step is to perform the Optimal Lag test. The Optimal Lag test aims to find out which lag is selected among other lag values. In addition, the purpose of the optimal lag test is because the endogenous variables from the endogenous variables in the system of equations will be used as exogenous variables. This test is also used to avoid if there is a kind of autocorrelation in the VAR analysis. In determining the optimal lag in this study using all information criteria. Estimation of the VAR model is carried out with an estimate with different lags and then compared with the value of the criteria. Finally, the smallest criterion value is selected to see the optimum lag value.

Cointegration Test (Johansen Cointegration Test) aims to determine whether the nonstationary variables are cointegrated or not. One method that can carry out the cointegration test is the Johansen Method developed by Johansen (1991). The Johansen method includes the Maximum Eigenvalue test and the Trace test. If in the co- 
integration test it is found that there is a long-term relationship between the observed variables, then the VECM model can be applied, but if it is not cointegrated, then the relevant model is unrestricted VAR.

$$
\begin{aligned}
& \lambda_{\text {Trace }}(r)=-T \sum_{i=r+1}^{g} i n\left(1-\lambda_{i}\right) \\
& \lambda_{\text {Max }}(r, r+1)=-T \operatorname{In}\left(1-\lambda_{r+1}\right)
\end{aligned}
$$

Its mean $\lambda \_i$ is estimated by value ith ordered eigenvalue. The standard approach to the Johansen method is that the maximum likelihood (ML) procedure is first to calculate the Trace and Maximum Eigenvalue statistics, then compare the appropriate critical values. In the co-integration test stage, if co-integration between variables or the co-integration rank is more than zero, the Vector Error Correction Model analysis can be carried out.

\section{Result and Discussion}

This study uses the Augmented Dicky Fuller Test and uses a critical value of 5 percent. If the value of the ADF test is less than the value of the Critical value, it can be concluded that the data is stationary or does not contain a unit root. The Table 2 provides information related to the results of the data stationarity test using the Augmented Dicky Fuller test. Following the results of the stationarity test, the data shows that all variables are stationary at the level except for population growth which is stationary at the second degree.

Table 2 Data Stationary Test Results with the Augmented Disky Fuller Test

\begin{tabular}{cccc}
\hline NO & Variable & Decision & Coefficient Value \\
\hline 1 & EG & Stationer in the Level & 0.0090 \\
2 & CPO & Stationer in the Level & 0.0001 \\
3 & GE & Stationer in the Level & 0.0000 \\
4 & GRI & Stationer in the Level & 0.0001 \\
5 & UP & Stationer in the Second Different & 0.0001 \\
\hline
\end{tabular}

Furthermore, the data is tested for the Lag Leg test to find out where this reflects the closest correct result to the Vector Error Correction Model test. The test results are presented in Table 3.

Table 3 Uji Lag Order Selection Criteria

\begin{tabular}{ccccccc}
\hline Lag & LogL & LR & FPE & AIC & SC & HQ \\
\hline 0 & -411.5691 & NA & 2062967 & 28.72890 & 28.96465 & 28.80274 \\
1 & -269.1044 & 225.9785 & 644.7147 & 20.62789 & $22.04233^{*}$ & 21.07088 \\
2 & -228.2548 & $50.70983^{*}$ & $255.9198^{*}$ & $19.53481^{*}$ & 22.12796 & $20.34696^{*}$ \\
\hline
\end{tabular}

The data is continued with further testing using the Johansen co-integration test to determine the relationship between variables in the long term. The test results are presented in Table 4. 
Qodri \& Wahyudi

Nexus between Issue of Environmental Pollution ...

Table 4 Unrestricted Cointegration Rank Test (Trace)

\begin{tabular}{ccccc}
\hline $\begin{array}{c}\text { Hypothesized No. } \\
\text { of CE }(\mathrm{s})\end{array}$ & Eigenvalue & Trace Statistic & $\begin{array}{c}0.05 \text { Critical } \\
\text { Value }\end{array}$ & Prob.** \\
\hline None* & 0.732550 & 110.846 & 69.81888 & 1.939544 \\
At most $1^{*}$ & 0.691596 & 72.600 & 47.85612 & 5.679189 \\
At most 2* & 0.460536 & 38.486 & 29.79707 & 0.003912 \\
At most 3* & 0.386686 & 20.587 & 15.49471 & 0.007811 \\
At most 4* & 0.198318 & 6.410 & 3.841465 & 0.011342 \\
\hline
\end{tabular}

From the results of the analysis using the Vector Error Correction Model (VECM) test, it can be shown the long-term and short-term relationship between the variables Economic Growth (EG), Gas Emissions $\mathrm{mtCO}_{2}(\mathrm{GE})$, Crude Palm Oil (CPO), Urban Populations (UP), and Gini Ratio Index (GRI).

Table 5 Vector Error Correction Model Test Results

\begin{tabular}{ccc}
\hline Variable & Coefficient & t-statistics \\
\hline CointEq1 & -0.736 & -1.390 \\
\hline Short term & & \\
D(EG(-2)) & 0.243 & 0.682 \\
\hline (CPO(-2)) & 0.019 & 0.090 \\
D(GE(-2)) & 0.074 & 0.253 \\
\hline (GRI(-2)) & -0.573 & -3.448 \\
D(UP(-2)) & 8.792 & 0.765 \\
Long term & & \\
CPO(-1) & -0.271 & -3.843 \\
GE(-1)) & -0.309 & -2.245 \\
GRI(-1)) & -0.577 & -6.195 \\
UP(-1)) & 0.256 & 3.131 \\
\hline
\end{tabular}

Note: significant level of $5 \%=2.0$

Based on the analysis results using the Vector Error Correction Model (VECM), it can be concluded that the dependent variable is Economic Growth. At the same time, the value of the ECT coefficient is -0.736 , which means that when all variables are in a dormant state, economic growth can decrease by 0.736 percent in one period of time.

$-0.736(\mathrm{ECT})-0.271(\mathrm{CPO}(-1))-0,309(\mathrm{GE}(-1))-0,577(\mathrm{GRI}(-1))+0.256(\mathrm{UP}(-1))+$ $0.243 \mathrm{D}(\mathrm{EG}(-2))+0.019 \mathrm{D}(\mathrm{CPO}(-2))+0,074 \mathrm{D}(\mathrm{GE}(-2))-0.573 \mathrm{D}(\mathrm{GRI}(-2))+8.792 \mathrm{D}(\mathrm{UP}(-2))+$ 6.247.

Results If viewed in the short-term Economic Growth has a positive and significant effect with a coefficient value of 0.243 . It means that when there is a 1 percent increase in economic growth this year, it will increase by 0.243 percent in the following year. The Indonesian economy itself in 2020, when measured by gross domestic product, reaches Rp. 15,434 trillion, while gross domestic product per capita reaches US\$3,911.7. (BPS, 2021). The economic structure in Indonesia so far tends to be spatially dominated by groups in the provinces on the island of Java by 58.75 percent, with economic 
performance experiencing a growth contraction of 2.51 percent. Of course, when compared to 2019 , this has decreased by 2.07 percent.

The impact of the Covid-19 pandemic in 2020 had a surprising impact on economic growth in Indonesia (Ali et al., 2021; Khanna, 2020; Maipas et al., 2021). It gives the impact of growth contraction that varies between islands. Island groups experiencing growth contraction (c-to-c) include the islands of Bali and Nusa Tenggara by 5.01 percent; Java Island by 2.51 percent; Kalimantan Island by 2.27 percent; and Sumatra Island by 1.19 percent. In contrast, the impact of Covid-19 was relatively not too severe on island groups that experienced increased growth, which included Sulawesi Island growing by 0.23 percent and Maluku and Papua Island by 1.44 percent. (BPS, 2021)

Likewise, CPO (Crude Palm Oil) directly impacts economic growth (Khatun et al., 2017). However, in this study, the coefficient value is 0.019 and has an effect but is not significant. Therefore, it can be interpreted if This is in line with what was conveyed by (Aprina, 2014; Kadarusman \& Herabadi, 2018; Sommer et al., 2019), which states that the majority of economic growth in developing countries is supported by agricultural commodities, one of which is palm oil.

In this case, Indonesia is also one of the developing countries that still cannot be separated from the agricultural sector. Despite efforts to shift to the industrial sector, support related to human resources is still lacking. So this could be one of the obstacles to the transition from the conventional sector to a more modern sector (Qodri et al., 2020; Wulandari et al., 2020). However, when viewed from increasing production, business development in the plantation sector has shown positive and very rapid progress, especially in oil palm commodities. It is also what makes Indonesia a mainstay for export to foreign markets.

In Indonesia, oil palm plantations are dominated in several areas, such as Java, Sumatra, and Kalimantan (Aprina, 2014). With abundant resources, Indonesia has become the most enormous crude palm oil production level globally. However, this cannot be separated from various factors that can support all of this, such as increased production, an increase in the quality of CPO that can penetrate the world market, and government policies to support all agricultural sectors. (Alatas, 2015) mentioned a downward trend in demand for Indonesian Crude Palm Oil. Of course, this must be vigilance for Indonesia so that exports continue to increase every year. (Iskandar, 2015) using the Autoregressive model found that in the short term, it has a positive effect on increasing Crude Palm Oil production on economic growth in Indonesia. It can be interpreted that palm oil commodities can positively impact increasing economic growth in a country in the short term.

As a comparison and reference, to see the impact of fluctuations or changes in international crude oil prices (Indonesian Crude-Oil Price) on the economy. (Nizar, 2012) conducted research using monthly time series data and the VAR model. The results of the analysis show that fluctuations in the price of international crude oil (Indonesian Crude-Oil Price) in the world market: first, have a positive impact on economic growth 
for three months (one quarter), second, encourage domestic inflation for one year, third, increase the money supply in the country; the increase in the money supply lasted for five months, fourth, had a negative impact on the real exchange rate of the rupiah for ten months and fifth, caused an increase in domestic interest rates (this effect lasted for ten months).

In contrast to the long-term results, Crude Palm Oil has a negative but significant effect, as indicated by the coefficient value of -0.271 . it can be interpreted that in the long term, every 1 percent growth of Crude Palm Oil production in the current year will have a decreasing impact on economic growth by 0.271 percent in the following year. (Tjahjaprijadi, 2014) stated that in the long term, Crude Palm Oil tends to have a negative impact on economic growth in Indonesia; this is due to the nature of the oil palm plant, which is prone to degradation of the quality of the planted soil so that its products will decrease over time.

Indeed, so far, Indonesia has become the largest palm oil-producing country in the world, but vigilance on the sustainability of biological resources must still be considered. Crude Palm Oil is a source of state revenue through trade. According to (Reiley, 2018) if the balance of payments is in a surplus, there is foreign exchange entering the country, so this can be beneficial for Indonesia in the short term and not in the long term.

Gas emission in this study shows a coefficient value of 0.074 , which is influential but not significant. This result can be interpreted that when there is a 1 percent increase in $\mathrm{CO}_{2}$ emissions in the current year, it will have an increasing impact on the economic growth of 0.074 percent in the following year. It was in line with what was conveyed by (FetahiVehapi et al., 2015; Frankel \& Romer, 1999) that $\mathrm{CO}_{2}$ emissions are related to a country's production and trade. Carbon emissions, in this case, are correlated with the intensity of economic activity in a country, especially developing countries (Muleya, 2020). In some instances, trade liberalization policies can minimize air pollutants that cause relatively high gas emissions, such as particulates and sulfur dioxide. (Cherniwchan, 2017).

The weakness of disclosing $\mathrm{CO}_{2}$ gas emissions in Indonesia is still minimal ( $\mathrm{Xu}$ et al., 2020). It is primarily voluntary and rarely implemented by business entities. Companies that disclose carbon emissions have several considerations, including gaining legitimacy from stakeholders, avoiding threats, especially for companies that produce greenhouse gases, such as increased operating costs, reduced demand, reputation risk, legal processes, and fines and penalties. (Berthelot \& Robert, 2011).

In contrast to the long term, gas emissions have a negative and significant coefficient value of -0.309 . Of course, this can be interpreted that every 1 percent increase in Gas Emissions this year, in this case, will have an impact on decreasing economic growth by 0.309 percent in the following year. By what was conveyed to (Wang et al., 2018), industrialization must lead to environmentally friendly sustainability so that this causes a decrease in economic growth in a country. In general, since the era of industrialization, every country has competed to produce and increase domestic productivity (Almer \& Winkler, 2017; Atik, 2012; Ghosh, 2019; Korkut et al., 2017). However, not many 
countries are aware of the impact (Dadhich et al., 2021; Li \& Jiang, 2018; Zhang et al., 2019).

One of the efforts to reduce the increase in gas emissions is implementing a policy on biofuels (Khatun et al., 2017; Seo et al., 2019). Thus, the industrialization of biodiesel can develop a green economy and is a positive response to energy conservation and emission reduction policies. However, promoting biodiesel production requires a tradeoff between economic and environmental targets (Xu et al., 2020).

In this case, the Gini Ratio Index has a coefficient value of -0.573 and has a significant effect. It can be interpreted that when there is a 1 percent increase in the Gini Index ratio this year, it will decrease economic growth by 0.573 percent in the following year. What was conveyed by (Bantika, Suzana, \& Kapantow, 2015) also mentions a significant influence between the Gini Coefficient Index and economic growth. Of course, when there is an increase in economic growth, there will be a reverse effect on the Gini Coefficient Index, where it will go down. It means that economic development is following one of the objectives, namely reducing income inequality in Indonesia.

However, when viewed from the Gini level, Indonesia's current ratio is still at 0.38 percent. According to (Nadya \& Syafri, 2019), income inequality between high-income people and low-income people is a big problem faced by developing countries, one of which is Indonesia. (Barika et al., 2010) mentioned that Indonesia is one of the countries with the highest Gini ratio globally, which can be assumed as the four most prosperous people in Indonesia and the 100 million poor people in the country. Therefore, this inequality in income distribution must focus on the government to provide more propoor policies to improve welfare and reduce the Gini ratio index.

Like the long term, the Gini Ratio Index, where this variable has a coefficient level of 0.577 and significantly affects economic growth in Indonesia. It means that every 1 percent increase in the Gini Ratio Index in Indonesia this year will impact decreasing economic growth by 0.577 percent in the following year. Inequality of development between regions is a common aspect in the economic activities of a region (Nadya \& Syafri, 2019). This inequality is caused by differences in the content of natural resources and geographical conditions in each region. As a result of these differences, the ability of a region to encourage the development process is also different. Therefore, it is not surprising that there are usually developed and underdeveloped areas (Gassner et al., 2019). Furthermore, the occurrence of inequality between regions has implications for the level of community welfare between regions. Therefore, this aspect of development inequality between regions also has implications for the regional government's formulation of regional development policies.

Urban Population, in this case, has a coefficient value of 8,792 and is influential but not significant. It can be interpreted that every 1 percent increase in population growth in the city in the current year will impact increasing economic growth by 8.79 percent in the following year. (Agung, Hartono, \& Awirya, 2017) explained that the level of urbanization in Indonesia is indeed very high. If it is calculated, almost more than half of 
the total population of Indonesia lives in urban areas (Rahmawati, 2020). The increase in urban population growth is directly proportional to future energy needs due to changes in people's energy consumption patterns caused by high demand and mobility in urban areas (Argüeso et al., 2013). Lifestyle changes will accompany urbanization and rapid urban population growth, changes in population settlement patterns, and improvements in transportation infrastructure, impacting increasing energy demand. It can be seen in the increasing lifestyle of urban people, who tend to be wasteful in energy use.

While the long-term urban population has a coefficient value of 0.256 and has a positive and significant effect on economic growth in Indonesia, this can be illustrated that when there is a 1 percent increase in the Urban Population-level, this year it will have a positive impact on economic growth in Indonesia in the following year. (Luber \& McGeehin, 2008) mentioned that the urban population, in this case, has played a role in economic growth in a country in general. However, this should be of particular concern when there is a deviation from this generalization. In extreme cases, some provinces (Central Kalimantan, Jambi, Papua, West Papua) are classified as more developed but still less urbanized or simply downward drifting due to poor infrastructure. On the other hand, Yogyakarta has a lower level of economic development than urbanization (Sulistyorini, 2020).

\section{Conclusion}

In achieving a goal of economic growth, the element of sustainability must remain a priority. Climate change is one of the impacts of every country that does not care about environmental health. Various industrial sectors have an impact on environmental sustainability, one of which is the palm oil industry. In this case, the palm oil industry, in the short term the palm oil industry, $\mathrm{CO}_{2}$ gas emissions, and the level of the urban population have a positive influence on economic growth in Indonesia except for the Gini ratio index, which has a negative influence on economic growth. Meanwhile, the palm oil industry emits $\mathrm{CO}_{2}$ gas in the long term, and the Gini index ratio has a negative effect. Therefore, it is due to environmental degradation that impacts the decline in long-term economic growth in Indonesia so far.

This study has limitations related to the object of research that only uses a few independent variables. It would be more interesting if this could use more variables to provide a broader explanation regarding the variables that affect economic growth and impact climate change in Indonesia.

Government policy should also pay attention to the environmental impact of any efforts to increase economic growth. If viewed from the short term, indeed most of the positive impact, but if viewed from the long term will be worried about the opposite impact. Indeed, this will create a moral burden for the sustainability of Indonesia in the future. 


\section{References}

Agung, P., Hartono, D., \& Awirya, A. A. (2017). Pengaruh urbanisasi terhadap konsumsi energi dan emisi $\mathrm{CO}_{2}$ : Analisis provinsi di Indonesia. Jurnal Ekonomi Kuantitatif Terapan, 10(1), 9-17. https://doi.org/10.24843/JEKT.2017.v10.i01.p02

Alatas, A. (2015). Trend produksi dan ekspor minyak sawit (CPO) Indonesia. AGR ARIS: Journal of Agribusiness and Rural Development Research, 1(2), 114-124. https://doi.org/10.18196/agr.1215

Ali, U., Herbst, C. M., \& Makridis, C. A. (2021). The impact of COVID-19 on the U.S. childcare market: Evidence from stay-at-home orders. Economics of Education Review, 82, [102094]. https://doi.org/10.1016/i.econedurev.2021.102094

Almer, C., \& Winkler, R. (2017). Analyzing the effectiveness of international environmental policies: The case of the Kyoto Protocol. Journal of Environmental Economics and Management, 82, 125-151. https://doi.org/10.1016/j.jeem.2016.11.003

Amalia, R., Dharmawan, A. H., Prasetyo, L. B., \& Pacheco, P. (2019). Perubahan tutupan lahan akibat ekspansi perkebunan kelapa sawit: Dampak sosial, ekonomi dan ekologi. Jurnal Ilmu Lingkungan, 17(1), 130. https://doi.org/10.14710/jil.17.1.130-139

Aprina, H. (2014). Analisis pengaruh harga crude palm oil (CPO) dunia terhadap nilai tukar riil rupiah. Buletin Ekonomi Moneter Dan Perbankan, 16(4), 315-338. https:// doi.org/10.21098/bemp.v16i4.15

Argüeso, D., Evans, J. P., Fita, L., \& Bormann, K. J. (2013). Temperature response to future urbanization and climate change. Climate Dynamics, 42(7-8), 2183-2199. https://doi.org/10.1007/s00382-013-1789-6

Atik, U. (2012). Pendugaan emisi $\mathrm{CO}_{2}$ sebagai gas rumah kaca akibat kebakaran hutan dan lahan pada berbagai tipe penutupan lahan di Provinsi Kalimantan Tengah tahun 20002009. Fakutas Kehutanan. Institut Pertanian Bogor.

Bahuet, C. (2017). Sustainable palm oil for all. United Nations Development Programme. Retrieved from https://www.id.undp.org/content/indonesia/en/home/presscenter/articles/2017/0 6/20/sustainable-palm-oil-for-all.html

Bantika, V., Suzana, B.O.L., \& Kapantow, G.H.M. (2015). Faktor-faktor yang mempengaruhi ketimpangan distribusi pendapatan di Sulawesi Utara. Cocos, 6(17). Retrieved from https://ejournal.unsrat.ac.id/index.php/cocos/article/view/10460

Barika, B., Armelly, A., \& Benardin, B. (2021). Tinjauan kausalitas indikator makroekonomi di provinsi Bengkulu. Convergence: The Journal of Economic Development, 2(2), 118-132. https://doi.org/10.33369/convergence-jep.v2i2.12536

Berthelot, S., \& Robert, A.-M. (2011). Climate change disclosures: An examination of Canadian oil and gas firms. Social And Environmental Accounting, 5(2), 106. https://doi.org/10.22164/isea.v5i2.61

Brown, D., Boyd, D. S., Brickell, K., Ives, C. D., Natarajan, N., \& Parsons, L. (2019). Modern slavery, environmental degradation and climate change: Fisheries, field, forests and factories. Environment and Planning E: Nature and Space, 4(2), 191-207. https://doi.org/10.1177/2514848619887156

Cabinet Secretariat of The Republic of Indonesia (Setkab). (2015). Prioritas Untuk Petani Marjinal, Pemerintah Segera Bagikan Lahan Seluas 9 Juta Hektar. Retrieved from https://setkab.go.id/prioritas-untuk-petani-marjinal-pemerintah-segera-bagikanlahan-seluas-9-juta-hektar/

Cherniwchan, J. (2017). Trade liberalization and the environment: Evidence from NAFTA and U.S. manufacturing. Journal of International Economics, 105, 130-149. https://doi.org/10.1016/i.jinteco.2017.01.005 
Dadhich, J., Smith, J. P., Iellamo, A., \& Suleiman, A. (2021). Climate change and infant nutrition: estimates of greenhouse gas emissions from milk formula sold in selected Asia Pacific Countries. Journal of Human Lactation, 37(2), 314-322. https://doi.org/10.1177/0890334421994769

Eka Yulian, B., Dharmawan, A. H., Soetarto, E., \& Pacheco, P. (2018). Livelihood dilemma of the rural household around the oil palm plantation in East Kalimantan. Sodality: Jurnal Sosiologi Pedesaan, 5(3), 1-8. https://doi.org/10.22500/sodality.v5i3.19398

Espeland, E. K., \& Kettenring, K. M. (2018). Strategic plant choices can alleviate climate change impacts: A review. Joumal of Environmental Management, 222, 316-324. https://doi.org/10.1016/i.jenvman.2018.05.042

Etale, L., \& Simatele, M. D. (2021). Climate change adaptation for food security and gendered-land rights in Western Kenya. Journal of Asian and African Studies, https://doi.org/10.1177\%2F0021909620988302

Fetahi-Vehapi, M., Sadiku, L., \& Petkovski, M. (2015). Empirical analysis of the effects of trade openness on economic growth: Evidence for south east European countries. Procedia economics and finance, 19, 17-26. https://doi.org/10.1016/s2212-5671(15)00004$\underline{0}$

Food and Agriculture Organization (FAO). (2018). Strong policies, certification key to sustainable oil palm production. Retrieved from http://www.fao.org/forestry/news/94861/en/

Frankel, J. A., \& Romer, D. (1999). Does trade cause growth? American Economic Review, 89(3), 379-399. https://doi.org/10.1257/aer.89.3.379

Gabungan Pengusaha Kelapa Sawit Indonesia (GAPKI) (2016). Refleksi industri kelapa sawit 2015 dan Prospek 2016. https://gapki.id/news/397/refleksi-industri-kelapa-sawit2015-dan-prospek-2016

Gassner, A., Harris, D., Mausch, K., Terheggen, A., Lopes, C., Finlayson, R., \& Dobie, P. (2019). Poverty eradication and food security through agriculture in Africa: Rethinking objectives and entry points. Outlook on Agriculture, 48(4), 309-315. https://doi.org/10.1177/0030727019888513

Ghosh, M. (2019). Climate-smart agriculture, productivity, and food security in India. Journal of Development Policy and Practice, 4(2), 166-187. https://doi.org/10.1177/2455133319862404

Greenpeace. (2013). Certifying Destruction. Retrieved from https://www.greenpeace.org/static/planet4-sweden-stateless/2019/01/69d1a6b869d1a6b8-rspo-certifying-destruction.pdf

Heizmann, B., \& Huth, N. (2021). Economic conditions and perceptions of immigrants as an economic threat in Europe: Temporal dynamics and mediating processes.

International Journal of Comparative Sociology, 62(1), 56-82. https://doi.org/10.1177/0020715221993529

Iskandar, A. (2015). Dampak perubahan harga crude palm oil (CPO) dunia terhadap value ekspor komoditas kelapa sawit dan perekonomian Indonesia (Pendekatan vector autoregression analysis). Journal Info Artha, 2(1), 1-17. Retrieved from http://jurnal.pknstan.ac.id/index.php/JIA/article/view/113

Jakob, T., \& Merk, H. F. (2011). Impact, impact, impact. Allergo Journal, 20(7), 371. https://doi.org/10.1007/bf03362565

Johansen, S. (1991). Estimation and hypothesis testing of cointegration vectors in gaussian vector autoregressive models. Econometrica, 59(6), 1551-1580.

https://doi.org/10.2307/2938278 
Kadarusman, Y. B., \& Herabadi, A. G. (2018). Improving sustainable development within indonesian palm oil: The importance of the reward system. Sustainable Development, 26(4), 422-434. https://doi.org/10.1002/sd.1715

Khanna, A. (2020). Impact of migration of labour force due to global COVID-19 pandemic with reference to India. Journal of Health Management, 22(2), 181-191. https://doi.org/10.1177/0972063420935542

Khatun, R., Reza, M. I. H., Moniruzzaman, M., \& Yaakob, Z. (2017). Sustainable oil palm industry: The possibilities. Renewable and Sustainable Energy Reviews, 76, 608-619. https://doi.org/10.1016/i.rser.2017.03.077

Korkut, N. E., Yaman, C., Küçükağa, Y., Jaunich, M. K., \& Demir, İ. (2017). Greenhouse gas contribution of municipal solid waste collection: A case study in the city of Istanbul, Turkey. Waste Management \& Research: The Journal for a Sustainable Circular Economy, 36(2), 131-139. https:// doi.org/10.1177/0734242x17744656

Kumar, U. (2019). Biosphere reserves of India: Issues of conservation and conflict. Journal of the Anthropological Survey of India, 68(1), 85-94. https://doi.org/10.1177/2277436x19845096

Laurance, W. F., Koh, L. P., Butler, R., Sodhi, N. S., Bradshaw, C. J. A., Neidel, J. D., ... Mateo Vega, J. (2010). Improving the performance of the roundtable on sustainable palm oil for nature conservation. Conservation Biology, 24(2), 377-381. https://doi.org/10.1111/j.1523-1739.2010.01448.x

Li, M., \& Wang, Q. (2017). Will technology advances alleviate climate change? Dual effects of technology change on aggregate carbon dioxide emissions. Energy for Sustainable Development, 41, 61-68. https://doi.org/10.1016/i.esd.2017.08.004

Li, R., \& Jiang, R. (2018). Is carbon emission decline caused by economic decline? Empirical evidence from Russia. Energy \& Environment, 30(4), 672-684. https://doi.org/10.1177/0958305×18802786

Luber, G., \& McGeehin, M. (2008). Climate change and extreme heat events. American Journal of Preventive Medicine, 35(5), 429-435. https://doi.org/10.1016/j.amepre.2008.08.021

Maipas, S., Panayiotides, I. G., Tsiodras, S., \& Kavantzas, N. (2021). COVID-19 pandemic and environmental health: effects and the immediate need for a concise risk analysis. Environmental Health Insights, 15. https://doi.org/10.1177/1178630221996352

Marshall, R.T. \& Arbuckle, W.S. (1996). Ice Cream. 5th Edition, Chapman \& Hall, New York.

Mubekti, M. (2013). Studi pewilayahan dalam rangka pengelolaan lahan gambut berkelanjutan di Provinsi Riau. Jurnal Sains Dan Teknologi Indonesia, 13(2), 88-94. https://doi.org/10.29122/jsti.v13i2.883

Muleya, E. (2020). Developmental social work and the sustainable development goals in south africa: opportunities and challenges. The International Journal of Community and Social Development, 2(4), 470-486. https:// doi.org/10.1177/2516602620975226

Nadya, A., \& Syafri, S. (2019). Analisis pengaruh faktor pertumbuhan ekonomi, pendidikan, dan pengangguran terhadap ketimpangan distribusi pendapatan di Indonesia. Media Ekonomi, 27(1), 37. https://doi.org/10.25105/me.v27i1.5300

Nizar, M. A. (2012). Dampak fluktuasi harga minyak dunia terhadap perekonomian Indonesia. Buletin Ilmiah Litbang Perdagangan, 6(2), 189-210. Retrieved from http://jurnal.kemendag.go.id/index.php/bilp/article/view/131

Perisai, R. A. (2020). Sawit dan lingkungan yang sakit: Perspektif analisis terhadap dampak negatif dalam pengelolaan perkebunan kelapa sawit di Indonesia. Retrieved from https:// fh.unpad.ac.id/sawit-dan-lingkungan-yang-sakit-perspektif-analisis-terhadapdampak-negatif-dalam-pengelolaan-perkebunan-kelapa-sawit-di-indonesia/

Purnomo, H., Okarda, B., Dermawan, A., Ilham, Q. P., Pacheco, P., Nurfatriani, F., \& Suhendang, E. (2020). Reconciling oil palm economic development and 
environmental conservation in Indonesia: A value chain dynamic approach. Forest Policy and Economics, 111, 102089. https://doi.org/10.1016/i.forpol.2020.102089

Qodri, L. A., Wulandari, D., \& Sumarsono, H. (2020). Food stability analysis in East Java. International Journal of Scientific and Technology Research, 9(2), 3712-3716. Retrieved from https://scholar.google.com/citations?view op=view citation\&hl=id\&user=Q37mlAAAAAJ\&citation for view=-Q37mlAAAAAJ:Tyk-4Ss8FVUC

Rahmawati, T. (2020). Urbanisasi dan polemik penduduk kota di Indonesia. https://doi.org/10.31219/osf.io/z74gw

Reiley, M. (2018). Rekor tertinggi, ekspor minyak sawit 2017 tembus US\$22,9 miliar. Retrieved from https://katadata.co.id/ekarina/berita/5e9a5609eb560/rekor-tertinggiekspor-minyak-sawit-2017-tembus-us-229-miliar

Ruggeri, M. (2019). Sustainable intensification in a forest-agriculture frontier landscape: Analysis of c capture and sequestration potential under two different scenarios in Binga district, Zimbabwe. Journal of Land and Rural Studies, 7(2), 169-194. https://doi.org/10.1177/2321024919844425

Science Daily. (2021). Palm oil: The carbon cost of deforestation. Retrieved from https://www.sciencedaily.com/releases/2018/06/180619123018.htm

Seo, H.-J., Kim, H., \& Jeon, E.-C. (2019). Economic effects of the liquid biofuel industry in South Korea using input-output analysis. Energy \& Environment, 31(3), 424-439. https://doi.org/10.1177/0958305x19874317

Shao, Q., Wang, X., Zhou, Q., \& Balogh, L. (2019). Pollution haven hypothesis revisited: A comparison of the BRICS and MINT countries based on VECM approach. Journal of Cleaner Production, 227, 724-738. https://doi.org/10.1016/j.jclepro.2019.04.206

Sjogersten, S. (2020). Palm oil: Research shows that new plantations produce double the emissions of mature ones. The Conversation. Retrieved from https://theconversation.com/palm-oil-research-shows-that-new-plantations-producedouble-the-emissions-of-mature-ones-130330

Sommer, J. M., Restivo, M., \& Shandra, J. M. (2019). India, palm oil, and ecologically unequal exchange: A cross-national analysis of forest loss. Sociological Perspectives, 63(2), 312332. https://doi.org/10.1177/0731121419888645

Sorsa, V.-P., \& Fougère, M. (2020). Toward political explanation of change in corporate responsibility: Political scholarship on CSR and the case of palm oil biofuels. Business \& Society, 1-27. https:// doi.org/10.1177/0007650320915919

Statistics Indonesia. (2021). Economic growth of Indonesia descend 2.07 percent (c-to-c). Retrieved from https://www.bps.go.id/pressrelease/2021/02/05/1811/ekonomiindonesia-2020-turun-sebesar-2-07-persen--c-to-chtml\#: : :text=Ekonomi $\% 20$ Indonesia $\% 20$ triwulan $\% 20 I V \% 2 D 2020 \% 20$ terhadap $\% 2$ Otriwulan $\% 20$ sebelumnya $\% 20$ mengalami $\% 20$ kontraksi,pengeluaran $\% 2 \mathrm{C} \% 20$ pertumb uhan $\% 20$ tertinggi $\% 20$ dicapai $\% 20$ oleh

Sulistyorini, A. (2020). From urbanization to ruralization. Monas, 2(1), 145-162. Retrieved from https://ejournal-bpsdm.jakarta.go.id/index.php/monas/article/view/38

Tjahjaprijadi, C. (2014). Dampak kenaikan harga minyak sawit internasional terhadap pertumbuhan ekonomi Indonesia. Retrieved from https:// fiskal.kemenkeu.go.id/kajian/2014/06/26/072952456782406-dampakkenaikan-harga-minyak-sawit-internasional-terhadap-pertumbuhan-ekonomi-indonesia

Union of Concerned Scientists. (2018). 2018 Annual Report. https://www.ucsusa.org/resources/2018-annual-report

United Nation. (2014). 2014 revision of the World Urbanization Prospects. Retrieved from https://www.un.org/en/development/desa/publications/2014-revision-worldurbanization-prospects.html 
USDA. (2021). Oilseeds: World markets and trade. Retrieved from https://www.fas.usda.gov/data/oilseeds-world-markets-and-trade

Vijay, V., Pimm, S. L., Jenkins, C. N., \& Smith, S. J. (2016). The impacts of oil palm on recent deforestation and biodiversity loss. PLOS ONE, 11(7). https://doi.org/10.1371/journal.pone.0159668

Wang, Z., Wei, W., Calderon, M., \& Liao, X. (2018). Impacts of biofuel policy on the regional economy and carbon emission reduction in Yunnan, China. Energy \& Environment, 30(5), 930-948. https://doi.org/10.1177/0958305x18813729

Wicke, B., Sikkema, R., Dornburg, V., \& Faaij, A. (2011). Exploring land use changes and the role of palm oil production in Indonesia and Malaysia. Land Use Policy, 28(1), 193-206. https://doi.org/10.1016/i.landusepol.2010.06.001

Wulandari, D., Narmaditya, B. S., Prayitno, P. H., Ishak, S., Sahid, S., \& Qodri, L. A. (2020). Nexus between production input and price commodity: An integration analysis of rice barns in east java of Indonesia. The Journal of Asian Finance, Economics and Business, 7(10), 451-459. https://doi.org/10.13106/jafeb.2020.vol7.no10.451

Xu, B., Zhong, R., \& Qiao, H. (2020). The impact of biofuel consumption on $\mathrm{CO}_{2}$ emissions: A panel data analysis for seven selected G20 countries. Energy \& Environment, 31(8), 1498-1514. https://doi.org/10.1177/0958305×20915426

Yang, L., \& Li, Z. (2017). Technology advance and the carbon dioxide emission in China Empirical research based on the rebound effect. Energy Policy, 101, 150-161. https://doi.org/10.1016/j.enpol.2016.11.020

Zeigler, R. S. (2019). Plant sciences, public policies, and food security. Outlook on Agriculture, 48(3), 220-228. https://doi.org/10.1177/0030727019868776

Zhang, R., Shen, G. Q., Ni, M., \& Wong, J. (2019). The relationship between energy consumption and gross domestic product in Hong Kong (1992-2015): Evidence from sectoral analysis and implications on future energy policy. Energy \& Environment, 31(2), 215-236. https://doi.org/10.1177/0958305x19854542 